\title{
Deskripsi Kemampuan Menulis Puisi Bebas Siswa Kelas VIII SMP Negeri 6 Watampone
}

\author{
Hapidah $^{1}$ \\ ${ }^{1}$ Guru SMP Negeri 6 Watampone \\ Email: hapidahrazak63@gmail.com
}

\begin{abstract}
Description of the Writing Ability of Class VIII Students at SMP Negeri 6 Watampone This study aims: 1) To understand the improvement in writing skills of Grade VIII students at SMP Negeri 6 Watampone, Bone Regency in terms of the structure of the scriptures. 2) to improve writing comprehension in class VIII of SMP Negeri 6 Watampone, Bone Regency in terms of poetry's inner structure. The design used in this research is quantitative descriptive which evaluates the research variables in the form of figures or statistics obtained from the results of tests consisting of the ability of students of class VIII of SMP Negeri 6 Watampone in Bone Regency in writing texts. Results Processing the data in this study discusses the ability of VIII A grade students of SMP Negeri 6 Watampone, Bone Regency in writing free poetry. Based on the results of data processing, it looks like the results of the ability tests of students of class VIII B Negeri 6 Watampone Bone Regency in writing free poetry depend on sufficient categories with an average value of 64.13.
\end{abstract}

Keywords : Description, Writing Ability, Poetry

Abstrak. Deskripsi Kemampuan Menulis Puisi Bebas Siswa Kelas VIII SMP Negeri 6 Watampone Penelitian ini bertujuan: 1) Untuk mengetahui peningkatan Kemampuan menulis puisi bebas siswa kelas VIII SMP Negeri 6 Watampone Kabupaten Bone ditinjau dari segi struktur fisik puisi. 2) Untuk mengetahui peningkatan Kemampuan menulis puisi bebas siswa kelas VIII SMP Negeri 6 Watampone Kabupaten Bone ditinjau dari segi struktur batin puisi. Desain yang digunakan dalam penelitian ini adalah bersifat deskriptif kuantitatif yang menggambarkan variabel penelitian dalam bentuk angka-angka atau statistik yang diperoleh dari hasil tes tertulis yang merupakan gambaran kemampuan siswa kelas VIII SMP Negeri 6 Watampone Kabupaten Bone dalam menulis sebuah puisi. Hasil pengolahan data pada penelitian ini memperlihatkan bahwa kemampuan siswa kelas VIII A SMP Negeri 6 Watampone Kabupaten Bone dalam menulis puisi bebas belum memadai. Berdasarkan hasil pengolahan data, tampak bahwa hasil tes kemampuan siswa kelas VIII B Negeri 6 Watampone Kabupaten Bone dalam menulis puisi bebas berada pada kategori cukup dengan nilai rata-rata 64,13 .

Kata Kunci: Deskripsi, Kemampuan Menulis, Puisi

\section{PENDAHULUAN}

Belajar bahasa adalah belajar komunikasi, dan belajar sastra adalah belajar menghargai manusia dan nilai-nilai kemanusiaan. Sastra merupakan bagian dari mata pelajaran bahasa dan sastra Indonesia yang memiliki fungsi utama sebagai penghalus budi pekerti, peningkatan kepekaan rasa kemanusiaan dan kepedulian sosial, penumbuh apresiasi budaya dan penyaluran gagasan, imajinasi dan ekspresi secara kreatif dan konstruktif, baik secara lisan maupun secara tulisan. Melalui sastra siswa diajak memahami, menikmati, dan menghayati karya sastra.

Sukristanto (dalam Sujarwanto, 2002: 550) menyebutkan bahwa memiliki keterampilan menulis memungkinkan seseorang mengomunikasikan gagasan, penghayatan, dan pengalamannya ke berbagai pihak terlepas dari ikatan waktu dan tempat. Dalam bahasa tulis, pemahaman pembaca 
atas sebuah tulisan bergantung pada rangkaian kata yang ditulis. Oleh karenanya, penggunaan bahasa khusunya penggunaan kalimat haruslah disusun sesuai dengan kaidah penulisan yang benar, kecuali karya sastra seperti puisi karena dalam puisi, terdapat kebebasan untuk pengarangnya (Sitaresmi, 2011: 1).

Menulis puisi merupakan bagian dari ekspresi sastra dalam standar kompetensi kajian bahasa Indonesia (Depdiknas, 2003). Keberadaan kompetensi ini di dalam kurikulum menunjukkan bahwa penguasaan terhadap keterampilan menulis puisi ini sangat penting dan sangat diperlukan.

Pembelajaran puisi dalam mata pelajaran Bahasa Indonesia bertujuan agar siswa dapat menyampaikan ide, gagasan, perasaan, dan pikiran dalam bentuk karya sastra yang disebut puisi. Nurgiyantoro (2005: 321) mengatakan bahwa puisi terbentuk oleh dua aspek yang saling berkaitan, yaitu sesuatu yang ingin diekspresikan dan sarana pengekspresian, yakni unsur isi dan bentuk. Unsur isi mencakup aspek gagasan, ide, emosi, atau lazim disebut tema, makna, sedang unsur bentuk, misalnya berupa berbagai aspek kebahasaan dan tipografinya.

Utami (dalam Kartini, 2011: 2) mengemukakan bahwa salah satu materi pembelajaran Bahasa dan Sastra Indonesia yang dianggap sulit oleh siswa adalah puisi, mulai dari menganalisa puisi, memaknai puisi, membaca puisi, hingga menulis puisi. Sementara itu, Nugiyantoro (2005: 312) berpendapat bahwa puisi adalah genre sastra yang amat memerhatikan pemilihan aspek kebahasaan sehinggan tidak salah jika dikatakan bahwa puisi adalah bahasa yang „tersaring" oleh penggunaannya.

Dari hasil observasi, diperoleh informasi bahwa kemampuan siswa dalam menulis puisi masih rendah. Hal ini dikarenakan guru atau penyelenggara pendidikan lebih memfokuskan siswa pada aspek pembacaan puisi, bukan pada aspek penulisan puisi. Hal ini dikarenakan kualitas proses pembelajaran kurang begitu diperhatikan oleh guru atau penyelenggara pendidikan lainnya sehingga hasilnya pun kurang sesuai dengan harapan. Hampir semua jenis sastra yang diajarkan di sekolah disajikan dengan cara-cara yang kurang bisa mengajak siswa untuk lebih kreatif dan inovatif. Semestinya sastra itu bisa menjadi pemicu munculnya kreativitas-kreativitas baru mengingat objek kajian sastra adalah daya imajinasi dan nilai rasa seseorang. Daya imajinasi akan memunculkan pemikiran- pemikiran baru yang sangat menunjang kreativitas seseorang, sedangkan nilai rasa akan menumbuhkan kepekaan seseorang terhadap fenomena-fenomena kehidupan yang terjadi. Dengan menggabungkan keduanya dalam pembelajaran, terutama pemebelajaran sastra, akan tercipta suasana pembelajaran yang lebih menyenangkan sehingga capaian hasil yang diinginkan akan memenuhi standar yang berlaku.

Berdasarkan latar belakang yang dikemukakan sebelumnya, rumusan masalah pada penelitian ini sebagai berikut:

1. Bagaimanakah kemampuan menulis puisi bebas siswa kelas VIII SMP Negeri 6 Watampone Kabupaten Bone ditinjau dari segi struktur fisik puisi?

2. Bagaimanakah kemampuan menulis puisi bebas siswa kelas VIII SMP Negeri 6 Watampone Kabupaten Bone ditinjau dari segi struktur batin puisi?

\section{METODE PENELITIAN}

Desain yang digunakan dalam penelitian ini adalah bersifat deskriptif kuantitatif.Deskriptif kuantitatif adalah rancangan penelitian yang menggambarkan variabel penelitian dalam bentuk angka-angka atau statistik yang diperoleh dari hasil tes tertulis. Angka atau statistik tersebut merupakan gambaran kemampuan siswa kelas VIII SMP Negeri 6 Watampone Kabupaten Bone dalam menulis sebuah puisi.

Untuk mendapatkan pengertian yang jelas atas variabel-variabel penelitian yang telah diidentifikasi, maka variabel tersebut perlu diuraikan secara operasional yaitu, kemampuan menulis puisi bebas adalah tingkat kesanggupan dan keterampilan siswa dalam menuangkan ekspresi dan daya imajinasinya dalam sebuah tulisan yang berbentuk puisi yang tidak terikat oleh syarat-syarat 
tertentu yang sesuai dengan struktur fisik dan struktur batin puisi. Selanjutnya pengertian struktur fisik dan stuktur batin puisi akan dijelaskan secara lebih terperinci sebagai berikut:

1. Struktur Fisik Puisi

a. Diksi atau pilihan kata adalah dasar bangunan setiap puisi. Diksi dapat dijadikan sebagai tolok ukur utuk penyair itu sendiri, mengenai daya cipta yang asli.

b. Pengimajian adalah gambaran angan yang terbentuk dan diekspresikan melalui medium bahasa yang merupakan hasil dari pengalaman indra manusia.

c. Kata konkret yaitu kata yang digunakan oleh seorang penyair untuk menunjukan suatu arti dari segi keseluruhan, dengan kata lain kata konret adalah kata-kata yang mampu memberikan pengimajian kepada pembaca atau pendengar.

d. Bahasa figuratif adalah bahasa yang digunakan oleh penyair untuk mendapatkan suatu kepuitisan.

e. Tipografi atau tata wajah puisi adalah bentuk tampilan suatu karya seorang penyair.

2. Struktur Batin Puisi

a. Tema adalah gagasan pokok atau subjeck-matter yang dikemukakan oleh penyair.

b. Perasaan adalah kondisi psikologi yang dirasakan oleh pembaca yang tercipta akibat adanya interaksi antar pembaca dengan puisi yang dibaca.

c. Nada adalah bunyi yang memiliki getaran teratur tiap diksi. Nada adalah bunyi yang beraturan memiliki frekuensi tunggal tertentu.

d. Amanat adalaha ajaran moral atau pesan yang ingin di sampaikan oleh pengarang melalui karyanya.

Populasi penelitian ini, yaitu keseluruhan siswa kelas VIII SMP Negeri 6 Watampone Kabupaten Bone yang berjumlah 139 orang yang terbagi atas 5 kelas. Populasi penelitian ini bersifat homogen. Untuk lebih jelasnya, penyebaran siswa tersebut berdasarkan kelas ditunjukkan pada tabel berikut:

Tabel 1. Keadaan Populasi

\begin{tabular}{|l|l|c|}
\hline No. & Kelas VIII & Jumlah \\
\hline 1. & VIII. A & 31 orang \\
2. & VIII. B & 32 orang \\
3. & VIII. C & 27 orang \\
4. & VIII. D & 29 orang \\
5. & VIII. E & 30 orang \\
& Jumlah & 139 orang \\
\hline
\end{tabular}

\section{HASIL DAN PEMBAHASAN}

\section{A. Hasil Penelitian}

Hasil kuantitatif yang dimaksudkan dalam penelitian ini adalah hasil yang dinyatakan dalam bentuk angka untuk mengetahui kemampuan rata-rata siswa dalam menulis puisi bebas ditinjau dari segi struktur fisik puisi (diksi, pengimajian, kata konkret, bahasa figuratif dan tipografi) dan ditinjau dari segi struktur batin puisi (tema, nada, perasaan dan amanat). Hal tersebut akan dirinci sebagai berikut:

1. Aspek-aspek kemampuan menulis puisi bebas siswa kelas VIII SMP Negeri 6 Watampone Kabupaten Bone Ditinjau dari segi struktur fisik puisi yaitu:

a. Kemampuan Menulis Puisi Bebas pada Aspek Diksi Siswa 
b. Kemampuan Menulis Puisi Bebas pada Aspek Pengimajinasian Siswa Kelas VIII SMP Negeri 6 Watampone Kabupaten Bone

c. Kemampuan Menulis Puisi Bebas pada Aspek Kata Konkret Siswa Kelas VIII SMP Negeri 6 Watampone Kabupaten Bone

d. Kemampuan Menulis Puisi Bebas pada Aspek Bahasa Figuratif Siswa Kelas VIII SMP Negeri 6 Watampone Kabupaten Bone.

e. Kemampuan Menulis Puisi Bebas pada Aspek Tipografi Siswa Kelas VIII SMP Negeri 6 Watampone Kabupaten Bone.

Hasil analisis data kemampuan menulis puisi bebas siswa kelas VIII SMP Negeri 6 Watampone Kabupaten Bone ditinjau segi struktur fisik puisi menunjukkan bahwa pada aspek diksi dan pengimajian siswa telah mampu menulis puisi bebas, sedangkan pada aspek kata konkret, bahasa figuratif dan tipografi siswa belum mampu menulis puisi bebas. Selain itu, ditinjau dari keseluruhan aspek ditinjau dari segi struktur fisik puisi hanya 1 orang atau $4 \%$ yang memeroleh nilai 75 ke atas, dengan nilai rata-rata 60,38 (cukup).

\section{Kemampuan Menulis Puisi Bebas Siswa Kelas VIII SMP Negeri 6}

Watampone Kabupaten Ditinjau dari Segi Struktur Batin Puisi yaitu :

a. Aspek-aspek Kemampuan Menulis Puisi Bebas pada aspek Perasaan Siswa Kelas VIII SMP Negeri 6 Watampone Kabupaten Bone

b. Aspek-aspek Kemampuan Menulis Puisi Bebas pada aspek Perasaan Siswa Kelas VIII SMP Negeri 6 Watampone Kabupaten Bone

c. Kemampuan Menulis Puisi Bebas pada Aspek Nada Siswa Kelas VIII SMP Negeri 6 Watampone Kabupaten Bone

d. Kemampuan Menulis Puisi Bebas pada Aspek Amanat Siswa Kelas VIII SMP Negeri 6 Watampone Kabupaten Bone

Hasil analisis data kemampuan menulis puisi bebas siswa kelas VIII SMP Negeri 6 Watampone Kabupaten Bone ditinjau segi struktur batin puisi menunjukkan bahwa pada aspek tema, perasaan dan amanat siswa telah mampu menulis puisi bebas, sedangkan pada aspek nada siswa belum mampu menulis puisi bebas. Selain itu, ditinjau dari keseluruhan aspek ditinjau dari segi struktur batin puisi hanya 4 orang atau 13\% yang memeroleh nilai 75 ke atas, dengan nilai rata-rata 66,12 (cukup). (Lampiran VII)

\section{A. Pembahasan}

Penelitian ini bertujuan untuk mendeskripsikan kemampuan menulis puisi bebas siswa kelas VIII SMP Negeri 6 Watampone Kabupaten Bone ditinjau dari segi struktur fisik puisi dan dari segi struktur batin puisi. Berdasarkan penyajian hasil analisis data, dapat diuraikan temuan yang diperoleh dalam penelitian ini. Hasil pengolahan data pada penelitian ini memperlihatkan bahwa kemampuan siswa kelas VIII.B SMP Negeri 6 Watampone Kabupaten Bone dalam menulis puisi belum memadai. Berdasarkan hasil pengolahan data, tampak bahwa hasil tes kemampuan siswa kelas VIII B SMP Negeri 6 Watampone Kabupaten Bone dalam menulis puisi bebas berada pada kategori cukup.

1. Kemampuan Menulis Puisi Bebas Siswa Kelas VIII SMP Negeri 6 Watampone Kabupaten Bone Ditinjau dari Segi Struktur Fisik Puisi.

a) Diksi (Pilihan Kata)

Hasil analisis data menunjukkan bahwa kemampuan menulis puisi bebas siswa kelas VIII SMP Negeri 6 Watampone Kabupaten Bone ditinjau dari aspek diksi siswa telah mampu menulis puisi bebas dengan tepat dengan persentase $84 \%$ dari keseluruhan jumlah siswa. 
b) Pengimajian (Daya Bayang)

Hasil analisis data menunjukkan bahwa kemampuan menulis puisi bebas siswa kelas VIII SMP Negeri 6 Watampone Kabupaten Bone ditinjau dari aspek pengimajian siswa telah mampu menulis puisi bebas dengan baik sekali dengan persentase $99 \%$ dari keseluruhan jumlah siswa. Berbeda dengan hasil penelitian yang dikemukakan oleh Fitriani (2006) yang mengemukakn hasil penelitian yang menunjukkan siswa kelas VII SMP Negeri 3 Makassar belum memadai.

c) Kata Konkret

Hasil analisis data menunjukkan bahwa kemampuan menulis puisi bebas siswa kelas VIII SMP Negeri 6 Watampone Kabupaten Bone ditinjau dari aspek kata konkret siswa telah mampu menulis puisi bebas dengan baik dengan persentase $71 \%$ dari keseluruhan jumlah siswa, namun masih kurang dari nilai ketuntasan yang telah ditetapkan sebesar $75 \%$.

d) Bahasa Figuratif

Hasil analisis data menunjukkan bahwa kemampuan menulis puisi bebas siswa kelas VIII SMP Negeri 6 Watampone Kabupaten Bone ditinjau dari aspek bahasa figuratif siswa telah mampu menulis puisi bebas dengan baik dengan persentase $69 \%$ dari keseluruhan jumlah siswa, namun masih kurang dari nilai ketuntasan yang telah ditetapkan sebesar $75 \%$.

e) Tata Wajah (Tipografi)

Hasil analisis data menunjukkan bahwa kemampuan menulis puisi bebas siswa kelas VIII SMP Negeri 6 Watampone Kabupaten Bone ditinjau dari aspek tipografi siswa telah mampu menulis puisi bebas dengan baik dengan persentase $63 \%$ dari keseluruhan jumlah siswa, namun masih kurang dari nilai ketuntasan yang telah ditetapkan sebesar $75 \%$.

Dari keseluruhan analisis data siswa tentang kemampuan menulis puisi bebas siswa kelas VIII SMP Negeri 6 Watampone Kabupaten Bone ditinjau dari segi struktur fisik puisi dinyatakan bahwa siswa belum mampu menulis puisi bebas sesuai dengan nilai hasil analisis data siswa dengan nilai rata-rata 60,62 (cukup), masih kurang dari nilai ketuntasan yang telah ditetapkan sebesar 75 .

2. Kemampuan Menulis Puisi Bebas Siswa Kelas VIII SMP Negeri 6 Watampone Kabupaten Bone Ditinjau dari Segi Struktur Batin Puisi.

a) Tema

Hasil analisis data menunjukkan bahwa kemampuan menulis puisi bebas siswa kelas VIII SMP Negeri 6 Watampone Kabupaten Bone ditinjau dari aspek tema, siswa telah mampu menulis puisi bebas dengan sangat baik dengan persentase $98 \%$ dari keseluruhan jumlah siswa.

b) Perasaan

Hasil analisis data menunjukkan bahwa kemampuan menulis puisi bebas siswa kelas VIII SMP Negeri 6 Watampone Kabupaten Bone ditinjau dari aspek perasaan siswa telah mampu menulis puisi bebas dengan baik dengan persentase $77 \%$ dari keseluruhan jumlah siswa.

c) Nada Puisi

Hasil analisis data menunjukkan bahwa kemampuan menulis puisi bebas siswa kelas VIII SMP Negeri 6 Watampone Kabupaten Bone ditinjau dari aspek nada siswa telah mampu menulis puisi bebas dengan baik dengan persentase $71 \%$ dari keseluruhan jumlah siswa, namun masih kurang dari nilai ketuntasan yang telah ditetapkan sebesar $75 \%$. 


\section{d) Amanat Puisi}

Hasil analisis data menunjukkan bahwa kemampuan menulis puisi bebas siswa kelas VIII SMP Negeri 6 Watampone Kabupaten Bone ditinjau dari aspek amanat siswa telah mampu menulis puisi bebas dengan baik dengan persentase $84 \%$ dari keseluruhan jumlah siswa.

Dari keseluruhan analisis data siswa tentang kemampuan menulis puisi bebas siswa kelas VIII SMP Negeri 6 Watampone Kabupaten Bone ditinjau dari segi struktur batin puisi dinyatakan bahwa siswa belum mampu menulis puisi bebas sesuai dengan nilai hasil analisis data siswa dengan nilai rata-rata 66,13 (cukup), masih kurang dari nilai ketuntasan yang telah ditetapkan sebesar 75 .

\section{KESIMPULAN}

Berdasarkan penyajian hasil analisis data dan pembahasan, dapat disimpulkan bahwa kemampuan menulis puisi bebas siswa kelas VIII SMP Negeri 6 Watampone Kabupaten, sebagai berikut :

1. kemampuan menulis puisi bebas siswa kelas VIII SMP Negeri 6 Watampone Kabupaten Bone ditinjau dari segi struktur fisik puisi (diksi, pengimajian, kata konkret dan bahasa figuratif) belum memadai.

2. kemampuan menulis puisi bebas siswa kelas VIII SMP Negeri 6 Watampone Kabupaten Bone ditinjau dari segi struktur batin puisi (tema, nada, perasaan dan amanat) belum memadai. Dengan demikian, dapat disimpulkan bahwa kemampuan menulis puisi bebas siswa kelas VIII SMP Negeri 6 Watampone Kabupaten Bone masih dikategorikan belum memadai. Hal ini dibuktikan dari jumlah persentase siswa yang memperoleh nilai di atas 75 hanya sebesar $13 \%$ tidak sesuai dengan kriteria ketuntasan yaitu $75 \%$.

\section{SARAN}

1. Pembelajaran menulis puisi perlu ditingkatkan sehingga kemampuan siswa dalam menulis puisi lebih meningkat dan dapat mengasah proses kreatif siswa dalam menulis karya sastra utamanya menulis puisi.

2. Pada pembelajaran menulis puisi diharapkan agar guru bidang studi dapat memberikan pemahaman tentang hal-hal yang perlu diperhatikan dalam menulis khususnya pada menulis puisi.

3. Hendaknya guru bahasa Indonesia di SMP Negeri 6 Watampone Kabupaten Bone selalu memberikan latihan atau tugas kepada siswa dalam menulis puisi yang kemudian memberitahukan letak kesalahan siswa dalam menulis puisi.

4. Bagi siswa, diharapkan mempunyai buku pegangan mengenai pembelajaran menulis, khususnya pada menulis puisi serta lebih banyak belajar dan berlatih pada pembelajaran menulis puisi.

5. Bagi sekolah, diharapkan dapat meningkatkan kualitas pembelajaran menulis puisi.

6. Bagi peneliti, diharapkan sebagai bahan acuan dan pedoman selanjutnya yang sejenis dengan penelitian ini. 


\section{DAFTAR PUSTAKA}

Arikunto, Suharsimi dkk. 2011. Penelitian Tindakan Kelas. Jakarta: Bumi Aksara.

Akhadiah, Sabarni, M.K. 1988. Evaluasi dalam Pengajaran Bahasa. Jakarta: Depdiknas

Akhadiah, S., Arsjad, G.M. \& Ridwan, S.H. 1996. Pembinaan Kemampuan Menulis Bahasa Indonesia. Jakarta. Erlangga.

Asma, Nur. 2006. Model Pembelajaran Kooperatif. Jakarta: Depdiknas.

Aminuddin, 1987. Pengantar Apresiasi Sastra. Bandung: Sinar Baru.

Arifin, Sari Rahayu. 2000. Pemanfaatan Media Gambar Seri dan Pengaruhnya terhadap Menulis Karangan Deskripsi Bahasa Indonesia Siswa Kelas VIII SMP Negeri 2 Maros. Skripsi. Makassar FBS UNM

Atmazaki. 1993. Analisis Sajak Teori, Metodologi dan Aplikasi. Bandung: Angkasa.

Aziz, dan Syukri Syamsuri, Andi, 2011. Apresiasi dan Kajian Puisi. Surabya: Penerbit Bintang Surabaya.

Badrun, Ahmad. 1983. Pengantar Ilmu Sastra. Surabaya: Usaha Nasional.

Berdianti, Ika. 2008. Membuat Puisi. Semarang: PT Sindur Press.

Berdianti, Ika. 2008. Perjalanan Panjang Satra Indonesia. Semarang: PT Sindur Press.

Carlyle, Pengertian Puisi dan Unsur-unsurnya diakses dari: http://abdurrosyid.wordpress.com/2009/07/27/puisi-pengertian-dan- unsur- unsurnya/

Depdiknas. 2003. Standar Kompetensi Mata Pelajaran Bahasa dan Sastra Indonesia. Jakarta: Depdiknas. 2005. Kamus Besar Bahasa Indonesia. Jakarta: Balai Pustaka. Effendi, S., 1996.

Bimbingan Apresiasi Puisi. Ende: Nusa Indah.

Endraswara, Suardi. 2011. Metode Pembelajaran Drama. Bandung: STSI Press

Enre, F.A. 1988. Dasar-dasar Keterampilan Menulis. Jakarta. Depdikbud. Dirjen Dikti.

Ellis, A., Panunu, J., Standal, T., \& Rummel, M.K. 1989. Elementary Language Arts Instruction. Englewood Cliffs, New Jersey: Printice Hall.

Fitriani, Andi. 2006. Kemampuan Siswa Kelas VII SMPN 3 Makassar Menulis

Puisi Berdasarkan Pengalaman Pribadi. Skripsi. Makassar FBS UNM.

Hasanuddin. 1996. Drama Karya dalam Dua Dimensi kajian Teori Sastra dan Analisi. Bandung: Angkasa.

Har. 2011, Langkah-langkah dalam Menulis Sebuah Puisi diakses dari: http://shaoran1401.blogspot.com/2014/04/menulis-puisi.html

Hardjono, S. 1988. Prinsip-prinsip Pengajaran Bahasa dan Sastra. Depdikbud. Jakarta.

Herlinah. 2006. Analisis Puisi dalam Deru Campur Debu Karya Chairil Anwar dalam perjuangan kemerdekaan. Skripsi. Unismuh: Makassar.

Ishaq Isjoni, 2010, Efektivitas Pembelajaran Kelompok, Bandung: Alfabeta.

Kartini. 2011. Peningkatan Kemampuan Menulis Puisi Bebas dengan Menggunakan Teknik Menulis Akrostik pada Siswa kelas VA semester II MI Semplak Pilar Kabupaten Bogor, Jurnal Pendidikan Dompet Dhuafa, Vol. I, No. 01, November 2011.

Khasanah, Umi. 2011. Meningkatkan Keterampilan Menulis Puisi bebas Menggunakan Mind Map untuk Siswa Kelas V Sekolah Dasar Negeri Soka UPT Kecamatan Wonosari Kabupaten Gunungkidul. Skripsi. Yogyakarta FIP UNY.

Kinani, Ristu. 2013. Peningkatan Keterampilan Menulis Puisi Bebas Menggunakan Model Active Learning Teknik Imajinasi Siswa Kelas V Sd Godegan Srandakan Bantul. Skripsi. Yogyakarta FIP UNY.

Kosasih. 2012. Dasar-Dasar Keterampilan Bersastra. Bandung: Yrama Widya.

Komaidi didik, 2011. Panduan Lengkap Menulis Kreatif, Jakarta: Sabda Media Koesasih, 
Kunandar, 2009, Langkah Mudah Penelitian Tindakan Kelas Sebagai Pengembangan Profesi Guru, Jakarta: PT Raja Grafindo Persada.

Sitaresmi, Nunung. 2011. Struktur Kalimat Bahasa Indonesia dalam Puisi Kontemporer. Artikel. Fakultas Bahasa dan Seni Universitas Pendidikan Indonesia.

Nurgiyantoro, Burhan. 2005. Sastra Anak: Pengantar Pemahaman Dunia Anak. Yogyakarta: Gadjah Mada University Press.

Kompetensi. Yogyakarta: BPFE.

Nurjamal, Daeng, dkk. (2011). Terampil Berbahasa: Menyusun Karya Tulis Akademik, Memandu Acara (MC-Moderator), dan Menulis Surat. Bandung: Alfabeta

Nurgiyantoro Burhan, 2010. Penelitian Pembelajaran Bahasa Berbasis Kompetensi, Yogyakarta: BPFE. Pradopo Ahmad, 2009 Pengkajian Puisi, Yogyakarta: Cetakan XI Gajah Mada Universitas Press.

Pradopo, Rachmat Djoko. 1987. Pengkajian Puisi Analisis Sastra Norma dan Analisis Struktural dan Semiotik. Yogyakarta: Gadjah Mada University Press. 1999. Pengkajian Puisi Analisis Sastra Norma dan Analisis Struktural dan Semiotik. Yogyakarta: Gadjah Mada University Press.

2002. Pengkajian Puisi Analisis Sastra Norma dan Analisis Struktural dan Semiotik. Yogyakarta: Gadjah Mada University Press. 2005. Pengkajian Puisi. Yogyakarta: Gadjah Mada

University Press.

Poerwadarminta, W.J.S. 2005. Kamus Umum Bahasa Indonesia. Jakarta: Balai Pustaka.

Riadl, Fahmi. 2008. Menulis adalah Berjuang. Diakses dari http; //menulis-kata.blogspot.com, tanggal 20 juni 2019

Rosliana. 2005. Analisis Gaya Bahasa dalam Kumpulan Puisi "Deru Campur Debu" Karya Chairil Anwar. Skripsi. Unismuh: Makassar

Rosyid, Abdur. 2009. Puisi : Pengertian dan Unsur-unsurnya. Diakses dari http://abdurrosyid.wordpress.com. Tanggal 20 juni 2019.

Semi, Atar. 1994. Kritik Sastra. Bandung: Angkasa.

Sihabuddin, dkk. 2009. Bahasa Indonesia 2. Surabaya: Amanah Pustaka. Siswanto, Wahyudi. 2008.

Pengantar Teori Sastra. Jakarta: Grasindo.

Sugiyono. 2014. Metode Penelitian Kuantitatif, Kualitatif dan R\&D. Bandung: Alfabeta.

Sujarwanto, dkk. 2002. Bahasa dan Sastra Indonesia Menuju Peran Transformasi

Sosial Budaya Abad XXI. Yogyakarta: Gama Media.

Sulastriningsih dan Mahmudah. 2007. Pengajaran Prosa Fiksi dan Drama. Makassar: Badan Penerbit UNM.

Tarigan, Henri Guntur. 2008. Menulis: Sebagai Suatu Keterampilan Berbahasa. Bandung: Angkasa.

Wahyuni, Ristri. 2014. Kitab Lengkap Puisi, Prosa, dan Pantun Lama. Yogyakarta: Saufa.

Waluyo, Herman J. 1995. Teori dan Apresiasi Puisi. Jakarta: Erlangga. 2002. Apresiasi Puisi. Jakarta: Gramedia Pustaka Utama 2005. Apresiasi Puisi. Jakarta: Gramedia Pustaka Utama Wardoyo, Sigit Mangun.

2013. Teknik Menulis Puisi. Yogyakarta. Graha Ilmu.

Warsidi, Edi. 2009. Pengetahuan Tentang Puisi. Bandung: Sarana Ilmu Pustaka.

Wordsworth, Dunton dan Tensoe Tjahjono, Pengertian Puisi Menurut Para Ahli, Diakses dari: http://nurfirstavhita.wordpress.com/2014/01/27/puisi-menurut-para-ahli-4-fungsibahasa-makna-puisi-aku-puisi-sumpah-pemuda/

Waluyo Herman J, 2007, Teori dan Apreasi Puisi, Jakarta: Gramedia Pustaka Utama.

Wassid Iskandar dan Sunendar, Dadang, 2009. Strategi Pembelajaran Bahasa, Bandung: PT Remaja Rosdakarya. 
Wordsworth, Dunton dan Tensoe Tjahjono, Pengertian Puisi Menurut Para Ahli, Diakses dari: http://nurfirstavhita.wordpress.com/2014/01/27/puisi-menurut-para-ahli-4-fungsibahasa-makna-puisi-aku-puisi-sumpah-pemuda/

Zainuddin. 1992. Materi Pokok Bahasa dan Sastra Indonesia. Jakarta: Rineka Cipta. 